\title{
Film yang Efektif sebagai Media Promosi Kesehatan bagi Masyarakat
}

\author{
R Yudi Rachman Saleh ${ }^{1}$, Insi Farisa Desy Arya ${ }^{2}$, Irvan Afriandi ${ }^{2}$ \\ ${ }^{1}$ Seksi Promosi Kesehatan, Bidang Bina Kesehatan Masyarakat, Dinas Kesehatan Kabupaten Ciamis dan \\ Program Studi Magister Ilmu Kesehatan Masyarakat, Fakultas Kedokteran Universitas Padjadjaran \\ ${ }^{2}$ Departemen Ilmu Kesehatan Masyarakat, Fakultas Kedokteran Universitas Padjadajaran
}

\begin{abstract}
Abstrak
Masalah kesehatan yang paling sering terjadi pada remaja adalah merokok. Penyebab yang paling berperan adalah pengaruh media audio visual, salah satu diantaranya yaitu iklan rokok. Salah satu upaya pencegahan dan penanggulangannya adalah kegiatan promosi kesehatan dengan media yang mudah diakses, menarik dan sesuai dengan karakteristik remaja yaitu film. Penelitian ini bertujuan untuk mengeksplorasi perancangan dan pembuatan media promosi kesehatan film pendek yang efektif tentang rokok dan bahayanya. Penelitian dilaksanakan pada Desember 2015 sampai dengan Januari 2016 yang disusun menggunakan desain kualitatif dengan paradigma kontruktivisme melalui metode kajian literatur dari 35 jurnal dan 16 buku teks dari internet dan perguruan tinggi. Hasil penelitian menyatakan jenis film yang efektif untuk menyampaikan pesan kesehatan khususnya tentang bahaya rokok harus memiliki 9 (sembilan) komponen pendukung yaitu tujuan pembuatan film, tema film, konten atau isi pesan, alur cerita yang jelas, konflik yang terjadi dalam cerita film, bahasa film, durasi penayangan film, tata artistik yang dikemas nyata untuk menarik dan menguatkan cerita serta penokohan yang ditampilkan dalam cerita film. Pada akhirnya remaja sebagai target penonton dapat tertarik dan antusias untuk melihat film tersebut dan dapat memperoleh pengetahuan yang lengkap, jelas dan benar, yang berujung pada peningkatan sikap serta menumbuhkan motivasi.
\end{abstract}

Kata kunci : Film, merokok, promosi kesehatan, remaja

\section{An Effective Movie as Health Promotion Media for Community}

\begin{abstract}
The most health problem often occurred among teenagers is smoking. The main perpetrator is audio-visual media, one of them is smoking product advertising. One of the preventing act and countermeasures in handling this problem is easy-to-access health promotion media in more appealing, entertaining,and appropriate for characteristic of youth that is a movie. The purpose of this study is to explore the design and making of an effective health promotion short movie about smoking and its danger. The study was held in December 2015 until January 2016 which arranged using qualitative design with constructivism through the method of literature review of 35 journals and 16 textbooks from internet and university. The results declared effective types of film to convey health messages about the dangers of smoking in particular must have 9 (nine) different support components, which are the aim of movie-making, the theme of the movie, content and message, clear plot and story flow, conflict of the story, the language of the movie, duration/the length of the movie, artistic layout which adds a sense of realness and strengthened the story, and the characterization appeared in the movie. In the end, teenagers as the audience target are able to be interested and enthusiastic to watch the movie and gain complete, clear and true comprehension which led to improve their attitude and motivation.
\end{abstract}

Keywords : Health promotion, movie, smoking, teenagers

Korespondensi:

R Yudi Rachman Saleh

Seksi Promosi Kesehatan, Bidang Bina Kesehatan Masyarakat, Dinas Kesehatan Kabupaten Ciamis dan Program Studi Magister Ilmu Kesehatan Masyarakat, Fakultas Kedokteran Universitas Padjadjaran Jl. Mriwa Kusumasomantri Ciamis 46213

Mobile : 087826392925

Email : yudirachman79@gmail.com 


\section{Pendahuluan}

Masalah perilaku kesehatan yang paling banyak pada remaja saat ini yaitu merokok. Faktor penyebab yang paling besar yaitu pengaruh media audio visual diantaranya iklan rokok. Saat ini remaja semakin mudah mengakses informasi dari berbagai perangkat media tanpa ada batasan. Pengaruh media sudah menyebar luas ke semua lingkungan pergaulan dan mengisi setiap waktu dalam kehidupan remaja baik di rumah maupun diluar rumah. Karakteristik remaja yang merupakan masa peralihan, masa mencari jati diri dengan emosi yang masih labil, sering bertindak tanpa memperhatikan akibat dapat menyebabkan penerimaan informasi yang salah tentang bahaya rokok.

Salah satu upaya pencegahannya yaitu melalui promosi kesehatan tentang bahaya rokok dengan menggunakan media yang mudah diakses, menarik dan sesuai karakteristik remaja yaitu film, tetapi banyak film yang dibuat untuk promosi kesehatan saat ini belum memberikan pengaruh terhadap perubahan perilaku karena dibuat asal-asalan. ${ }^{1}$ Film merupakan media audio visual yang paling tepat dan alat komunikasi yang kuat sebagai media promosi kesehatan karena melibatkan banyak indera terutama indera penglihatan serta indera pendengaran. ${ }^{2-4}$ Film juga memiliki kelebihan menarik perhatian sekaligus bersifat edukatif dan menghibur. ${ }^{5-7}$

Film dapat memberikan pengaruh negatif berkaitan dengan kebiasaan merokok pada remaja. Paparan film yang terdapat konten rokok merupakan faktor resiko yang memberikan efek memperkuat niat merokok kepada remaja..$^{8-12}$ Remaja yang melihat konten merokok dalam film memiliki kemungkinan 3 kali lebih besar memulai merokok. ${ }^{12,13}$ Semakin sering remaja terpapar maka semakin besar kemungkinan memunculkan niat merokok dalam 30 hari kemudian dan selanjutnya menjadi perokok tetap, karena gambaran merokok di film memainkan peran yang besar untuk mendefinisikan dirinya sebagai seorang perokok. ${ }^{9,13,14}$ Selain itu remaja yang melihat bintang idolanya merokok akan menimbulkan keinginannya untuk merokok dan akan mempengaruhi sikap serta perilakunya yang kemudian akan menjadi perokok tetap pada 3 tahun kemudian. ${ }^{9,12,15-17}$

Selain efek negatif film juga dapat menjadi peluang baik untuk mengenalkan nilai positif serta menjadi media yang efektif dalam promosi kesehatan tentang bahaya rokok kepada remaja, diantaranya menampilkan film pendek dengan pesan anti rokok sebelum penayangan film yang didalamnya terdapat konten merokok yang akan membantu mencegah remaja untuk memiliki niat atau keinginan merokok serta memunculkan pikiran negatif terhadap karakter yang merokok. ${ }^{15,17}$ Film juga merupakan media yang sesuai dan tepat untuk remaja dan apabila diperlihatkan secara berulang maka akan memberikan dampak yang kuat pada pribadinya. $^{2-4,8}$

Melalui film promosi kesehatan anti rokok remaja dapat memperoleh pengetahuan yang lengkap, jelas dan benar tentang dampak buruk rokok bagi kesehatan, sehingga dapat meningkatkan sikap berupa pengendalian diri untuk tidak merokok dan menumbuhkan kepercayaan diri menolak merokok dan memotivasi untuk tidak merokok meskipun ada pengaruh dari lingkungan sekitarnya seperti keluarga, teman sebaya dan pengaruh industri rokok melalui media terutama iklan rokok yang menarik, akhirnya remaja memiliki perilaku yang positif terhadap bahaya rokok bagi kesehatan. Penelitian ini bertujuan untuk mengetahui perancangan dan pembuatan media promosi kesehatan film yang efektif tentang rokok dan bahayanya, sehingga bermanfaat sebagai acuan dalam membuat media promosi kesehatan film khususnya tentang bahaya rokok pada kesehatan bagi remaja.

\section{Metode}

Penelitian dilaksanakan pada bulan Desember 2015 sampai Januari 2016. Menggunakan desain kualitatif dengan paradigma konstruktivisme melalui metode kajian literatur dengan objek penelitian yaitu 35 artikel jurnal dari sumber

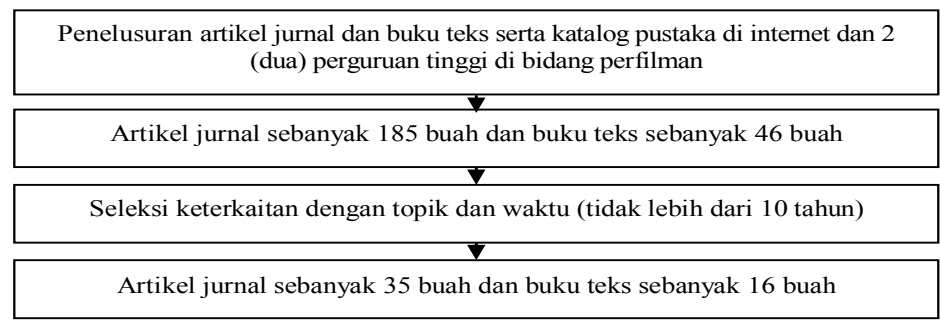

Bagan 1 Pencarian dan Seleksi Artikel Jurnal dan Buku Teks 
yang sudah terakreditasi dan 16 buku teks yang berbahasa Inggris dan bahasa Indonesia dengan kriteria inklusi yaitu objek berasal dari jurnal, katalog pustaka di internet dan perguruan tinggi dengan kata kunci film pendek dan media promosi kesehatan, sedangkan kriteria ekslusi yaitu artikel jurnal dan buku teks yang tahun penerbitannya lebih dari 10 tahun. Pengolahan data dengan analisis isi dan disusun teorisasi sehingga diperoleh teori substantif.

\section{Hasil}

Hasil penelusuran artikel jurnal dan buku teks diperoleh 35 artikel jurnal dan 16 buku teks. Evaluasi data membagi artikel jurnal dan buku teks yang disusun berdasarkan karakteristik. Tahap selanjutnya yaitu menganalisis dan menginterpretasikan data sehingga didapatkan parameter dan kriteria film yang efektif sebagai media promosi kesehatan tentang rokok dan bahayanya, terlihat pada gambar 1 .

\section{Tabel 1 Kategori Artikel Jurnal}

\begin{tabular}{|c|c|c|}
\hline Kode & Nama Penulis dan Tahun Terbit & Judul \\
\hline & \multicolumn{2}{|l|}{ Artikel jurnal dengan design deskriptif } \\
\hline A1 & Ariansah M (2005) & Apakah film itu? \\
\hline A2 & Wibawa B (2005) & Film Sebagai Seni \\
\hline A3 & E Bennett, N Maniar (2007) & Are Videoed Lecture an Effective Teaching Tool? \\
\hline A4 & Ariansah M (2010) & Kritik Atas Konsep Film Sebagai Bahasa Visual \\
\hline A5 & Doeana BB (2011) & Menata Artistik Dalam Film dan Televisi. \\
\hline A6 & Curse E (2011) & $\begin{array}{l}\text { Using Educational Video in the Classroom : Theory, } \\
\text { Research and Practice. }\end{array}$ \\
\hline A7 & Adisusilo S (2012) & Pengembangan Media Pembelajaran dan Sumber Ajar \\
\hline A8 & Gita R (2012) & Naratif dan Realisme Sinetron \\
\hline A9 & Alamsyah (2012) & Perspektif Dakwah Melalui Film. Jurnal Dakwah Tabligh \\
\hline A10 & Astonia O (2012) & Budaya Film Horor Dalam Wajah Perfilman Indonesia \\
\hline A11 & Bhanuteja RW (2012) & Bahasa Film Menggunakan Bau \\
\hline A12 & Koeshardanto TW, Masnuna (2013) & $\begin{array}{l}\text { Film Pendek Bertema Nasionalisme Menggunakan Potrait } \\
\text { Screen Angel dan Teknik Special Effect }\end{array}$ \\
\hline A13 & Pramana IGGAB (2012) & $\begin{array}{l}\text { Kualitas Perfilman Indonesia Dalam Kaitannya Dengan } \\
\text { Kualitas Penonton Indonesia }\end{array}$ \\
\hline \multirow[t]{2}{*}{ A14 } & $\begin{array}{l}\text { Utomo P, Purnama BE, Urbani YH } \\
(2015)\end{array}$ & $\begin{array}{l}\text { Produksi Film Pendek "Like And Dislike" Menggunakan } \\
\text { Sistem Multimedia }\end{array}$ \\
\hline & \multicolumn{2}{|c|}{ Artikel jurnal dengan design literatur review } \\
\hline A15 & Charlesworth A, Glantz SA (2005) & $\begin{array}{l}\text { Smoking In The Movies Increases Adolescent Smoking: A } \\
\text { Review }\end{array}$ \\
\hline \multirow[t]{2}{*}{ A16 } & Jerrick D (2013) & $\begin{array}{l}\text { The Efectiveness of Film Trailer: Evidence from the } \\
\text { College Student Market }\end{array}$ \\
\hline & \multicolumn{2}{|c|}{ Artikel jurnal dengan design cross sectional } \\
\hline A17 & $\begin{array}{l}\text { Song AV, Ling PM, Neilands TB, Glantz } \\
\text { SA (2007) }\end{array}$ & $\begin{array}{l}\text { Smoking In Movies And Increased Smoking Among Young } \\
\text { Adults }\end{array}$ \\
\hline A18 & $\begin{array}{l}\text { Thrasher JF, Jackson C, Santillan EA, } \\
\text { Sargent JD (2008) }\end{array}$ & $\begin{array}{l}\text { Exposure To Smoking Imagery In Popular Films And } \\
\text { Adolescent Smoking In Mexico }\end{array}$ \\
\hline A19 & Sargent JD et al (2011) & $\begin{array}{l}\text { Effect Of Seeing Tobacco Use In Films On Trying Smoking } \\
\text { Among Adolescents: Cross Sectional Study }\end{array}$ \\
\hline A 20 & $\begin{array}{l}\text { Hunt K, Henderson M, Wight D, Sargent } \\
\text { JD (2011) }\end{array}$ & $\begin{array}{l}\text { Exposure To Smoking In Films And Own Smoking Among } \\
\text { Scottish Adolescents: A Cross Sectional Study }\end{array}$ \\
\hline
\end{tabular}


Artikel jurnal dengan design kuasi eksperimen

A21 Edwards C, Oakes W, Bull D (2007) Out Of The Smokescreen II: Will An Advertisement Targeting The Tobacco Industry Affect Young People's Percption Of Smoking In Movie And Their Intention To Smoke?

A22 Kumboyono (2011)

Perbedaan Efek Penyuluhan Kesehatan Menggunakan Media Cetak dengan Media Audio Visual Terhadap Peningkatan Pengetahuan Pasien Tuberkulosis

A23 Nurjanah E (2013)

Pengaruh Media Film Trehadap Motivasi Belajar Siswa dalam Pembelajaran Pendidikan Kewarganegaraan (PPKN)

Artikel jurnal dengan design studi longitudinal

A24 Thrasher JF, Sargent JD, Huang L, Does Film Smoking Promote Youth Smoking In Middle Santillan EA, Alonso AD, Hernandez RP Income Countries? A Longitudinal Study Among Mexican (2009) Adolescents

A25 Anderson SJ, Millett C, Polansky JR, Exposure To Smoking In Movie Among British Adolescents Glantz SA 2001-2006

A26 Primack BA, Longacre MR, Beach ML,

Association Of Established Smoking Among Adolescents Mejia AMA, Titus LJ, Dalton MA (2012)

With Timing Of Exposure To Smoking Depicted In Movies

\begin{tabular}{ll} 
& Artikel jurnal dengan design studi kasus \\
\hline A27 & $\begin{array}{l}\text { Dixon HG, David JH, Borland R, Paxton } \\
\text { SJ (2011) }\end{array}$
\end{tabular}

A28 Basuki TN, Irawan AH (2012)

A29 Adhityaksa C (2012)

Public Reaction To The Portrayal Of The Tobacco Industry In The Film The Insider

Perancangan Film Pembelajaran Kesenian Ludruk untuk Sekolah Menengah Pertama Kelas VII di Surabaya

Program Televisi yang Dibutuhkan dan Diminati Studi Kasus Komedi Situasi Bajaj Bajuri

A30 Abidin Z (2013)

Mise-en-scene dalam Sang Penari-nya Ifa Isfansah

Artikel jurnal dengan design studi kohort

A31 Waylen AE, Leary SD, Ness AR, Tanski SE, Sargent JD (2011)

Cross Sectional Association Between Smoking Depictions In Films And Adolescent Tobacco Use Nested In A British Cohort Study

\begin{tabular}{|c|c|c|}
\hline & Artikel jurnal dengan design discrete time & survival analysis \\
\hline \multirow[t]{2}{*}{ A32 } & $\begin{array}{l}\text { Farrelly MC, Kamyab K, Nonnemaker J, } \\
\text { Crankshaw E, Allen JA (2012) }\end{array}$ & $\begin{array}{l}\text { Movie Smoking And Youth Initiation: Parsing Smoking } \\
\text { Imagery And Other Adult Content }\end{array}$ \\
\hline & \multicolumn{2}{|c|}{ Artikel jurnal dengan model ADDIE (Analysis, Design, Development, Implementation, Evaluation) } \\
\hline A33 & Syafrudin C, Pujiyono W (2013) & $\begin{array}{l}\text { Pembuatan Film Animasi Pendek "Dahsyatnya Sedekah" } \\
\text { Berbasis Multimedia Menggunakan Teknik 2D Hybrid } \\
\text { Animation dengan Pemanfaatna Graphic }\end{array}$ \\
\hline \multirow[t]{2}{*}{ A34 } & Avcioglu H (2013) & $\begin{array}{l}\text { Effectiveness of Video Modelling in Training Students with } \\
\text { Intellectual Disabilities to Greet People When They Meet }\end{array}$ \\
\hline & \multicolumn{2}{|c|}{ Artikel jurnal dengan design eksperimental } \\
\hline A35 & $\begin{array}{l}\text { Sugiarsana IKJS, Darmawiguna IGM, } \\
\text { Wirawan IMA (2015) }\end{array}$ & $\begin{array}{l}\text { Pengembangan Film Pembelajaran Musim Penghujan Pada } \\
\text { Tema Peristiwa Alam Untuk Siswa Kelas } 1 \text { Sekolah Dasar } \\
\text { Laboratorium UNDIKSHA Singaraja }\end{array}$ \\
\hline
\end{tabular}




\section{Tabel 2 Kategori Buku Teks}

\begin{tabular}{|c|c|c|}
\hline Kode & Pengarang dan Tahun Terbit & Judul \\
\hline B1 & Perasi DA (2005) & Film/Media/Seni \\
\hline B2 & Prakosa G (2005) & $\begin{array}{l}\text { Film Pendek Independen Dalam Penilaian (Sebuah Catatan } \\
\text { dari Berbagai Festival "Film Pendek dan Film Alternatif" di } \\
\text { Indonesia) Cetakan Perdana. }\end{array}$ \\
\hline B3 & Notoatmodjo S (2007) & Pendidikan dan Perilaku Kesehatan \\
\hline B4 & Arsyad A (2007) & Media Pembelajaran \\
\hline B5 & Prakosa G (2008) & $\begin{array}{l}\text { Film Pinggiran (Antologi Film Pendek, Film Eksperimental } \\
\text { dan Film Dokumenter). }\end{array}$ \\
\hline B6 & Info Reports (2008) & Entertainment Education for Better Health \\
\hline B7 & Pratista H (2008) & Memahami Film \\
\hline B8 & Effendy H (2009) & $\begin{array}{l}\text { Mari Membuat Film (Panduan Menjadi Produser) Edisi } \\
\text { Kedua }\end{array}$ \\
\hline B9 & Tirtayasa (2011) & $\begin{array}{l}\text { Film Pendidikan Ditinjau Dari Perspektif Kajian Ilmu } \\
\text { Komunikasi }\end{array}$ \\
\hline $\mathrm{B} 10$ & Joseph V. Mascelli, A.S.C (2010) & The Five C's of Cinematography (Lima Jurus Sinematografi) \\
\hline B11 & Sanjaya W (2012) & Media Komunikasi Pembelajaran \\
\hline B12 & $\begin{array}{l}\text { Sadiman S, Rahardjo R, Haryono A, } \\
\text { Rahardjito (2012) }\end{array}$ & $\begin{array}{l}\text { Media Pendidikan (Pengertian, Pengembangan, dan } \\
\text { Pemanfaatannya) }\end{array}$ \\
\hline B13 & Daryanto (2013) & $\begin{array}{l}\text { Media Pembelajaran (Peranannya sangat penting dalam } \\
\text { mencapai tujuan pembelajaran). }\end{array}$ \\
\hline B14 & Munadi Y (2013) & Media Pembelajaran (Sebuah Pendekatan Baru) \\
\hline B15 & Suyanto M (2013) & The Oscar Winner dan Box Office: The Secret of Screenplay \\
\hline B16 & Kholid A (2014) & $\begin{array}{l}\text { Promosi Kesehatan dengan Pendekatan Teori Perilaku, } \\
\text { Media dan Aplikasinya (Untuk Mahasiswa dan Praktisi } \\
\text { Kesehatan) }\end{array}$ \\
\hline
\end{tabular}

Tujuan Film. Tujuan film yaitu sebagai media komunikasi yang dapat menyampaikan pesan kepada khalayak. Sebagai media komunikasi yang baik film memiliki 3 tujuan yaitu sebagai sarana informasi, sarana pembelajaran dan sarana hiburan. Sarana Informasi; Film sebagai sarana informasi dapat menyampaikan informasi yang baik dan benar, sesuai dengan kenyataan, tidak direkayasa, masuk akal atau dibesar-besarkan. Sarana pembelajaran; Film sebagai sarana pembelajaran dapat memberikan pembelajaran yang positif sehingga dapat ditiru dan digunakan sebagai bahan ajar di sekolah dengan tujuan dapat meningkatkan pengetahuan, penanaman kognitif, psikomotorik dan pembentukan afektif. Sarana hiburan; Film yang menarik adalah yang dapat memberikan tontonan yang menghibur sekaligus dapat memasukan pesan positif baik dalam bentuk simbol, gambar atau dialog sehingga penonton baik sengaja maupun tidak sengaja memahami pesan yang disampaikan.

Tema film. Penyampaian tema film akan menarik dan memudahkan penonton untuk mengetahui seperti apa film yang akan dilihatnya. Penentuan tema dalam sebuah film harus utuh, menarik dan mengandung nilai serta makna. Tema cerita utuh; Film yang menyampaikan temanya secara utuh yaitu ada kesesuaian antara tema film dengan keseluruhan isi cerita yang disampaikan mulai dari awal sampai dengan akhir. Tema menarik; Tema film harus disukai dan dapat dipahami maksudnya oleh penonton serta membuat penonton penasaran untuk terus mengikuti adegan demi adegan dalam cerita film. Tema mengandung nilai dan makna; Tema film harus memiliki manfaat dan fungsi positif bagi penontonya, sehingga penonton tidak hanya menonton karena tema film yang disukainya saja tetapi memperoleh manfaat pembelajaran setelahnya.

Konten atau isi pesan pada film. Penyampaian konten atau isi pesan dalam suatu film harus memperhatikan kemudahan penonton menerima pesan yang disampaikan, kejelasan pesan yang disampaikan, pesan moral yang terkandung 


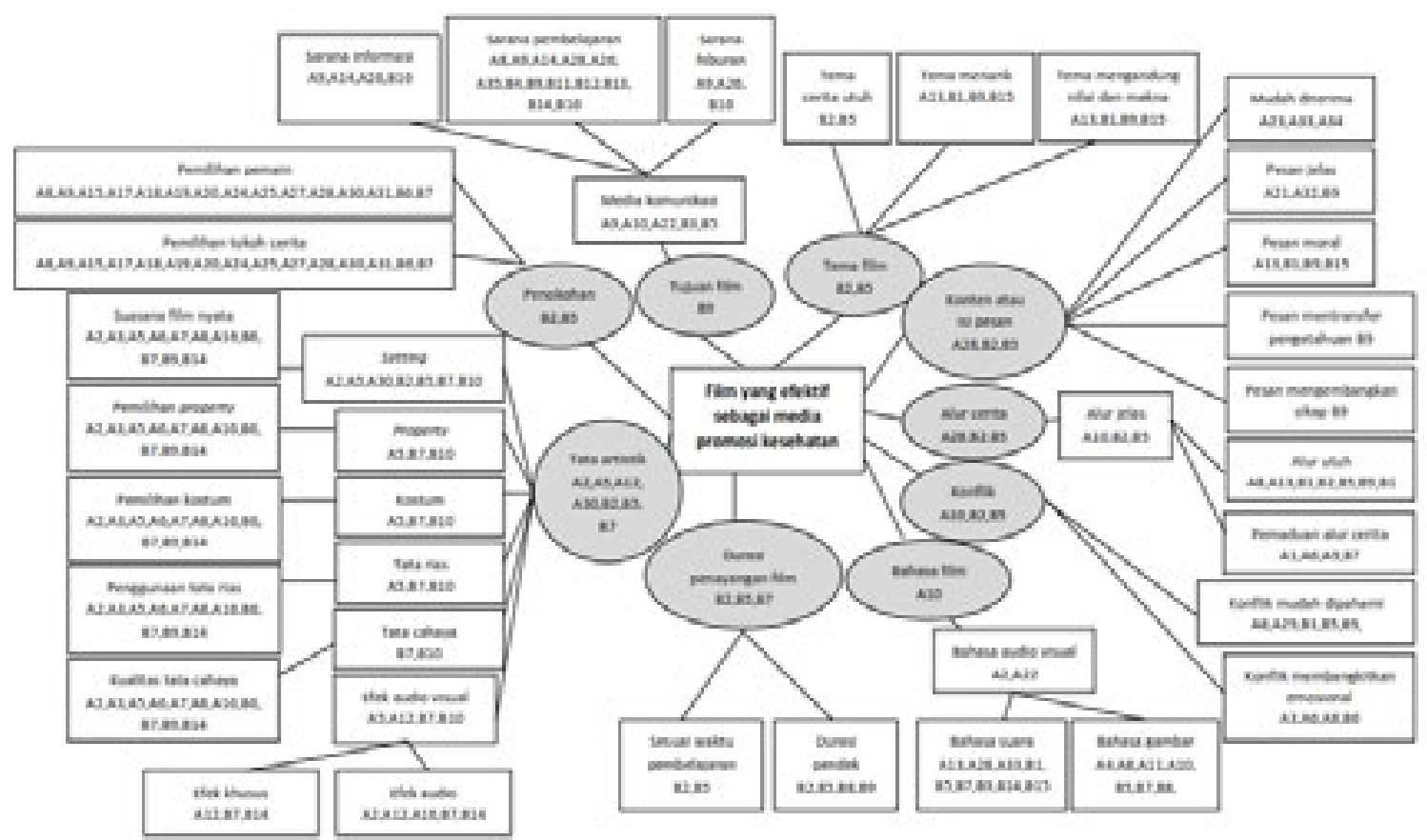

\section{Gambar 1 Parameter dan Kriteria Film yang Efektif Sebagai Media Promosi Kesehatan Tentang Rokok dan Bahayanya}

didalamnya, fungsi pesan untuk mentransfer pengetahuan dan pesan yang disampaikan dapat mengembangkan sikap. Mudah diterima; Konten atau isi pesan pada film yang mudah diterima penonton yaitu menyesuaikan dengan kebutuhan, karakteristik, minat dan kondisi penonton, selain itu pemain yang terlibat harus sesuai sehingga pesan yang disampaikan melalui tokoh yang ditampilkan bisa diterima oleh penonton. Pesan jelas; Konten dan isi pesan secara jelas menyampaikan pesan kepada penonton tentang sesuatu yang pantas dan tidak pantas ditiru sehingga pesan yang disampaikan akan mampu membentuk karakter yang positif. Pesan Moral; Konten atau isi pesan mengadung pesan moral yang baik dan mendidik dengan menggunakan bahasa yang sederhana dan mudah dipahami. Pesan mentransfer pengetahuan; Konten atau isi pesan dapat mentrasfer pengetahuan yang positif, nyata dan benar kepada penonton. Pesan mengembangkan sikap; Konten dan isi pesan dapat menumbuhkan sikap mental yang kuat dalam hal ini yaitu sikap untuk tidak merokok dan menolak merokok.

Alur cerita. Alur atau jalan cerita film digambarkan dengan jelas sehingga penonton mengetahui arah dari cerita film, yaitu alur digambarkan utuh dan dalam proses pemaduan gambar harus mengikuti alur yang sudah direncanakan dalam pembuatan skenario. Alur utuh; Alur utuh mulai dari awal sampai dengan akhir cerita dan antara tiap adegan dengan keseluruhan cerita harus memiliki hubungan, tidak berdiri sendiri, memiliki keterkaitan serta diakhiri cerita yang jelas. Pemaduan alur cerita; Menghasilkan alur yang berhubungan dapat dilakukan dengan pembuatan skenario serta pemaduan adegan film yang ceritanya dibuat saling mendukung dan berhubungan.

Konflik. Menonjolkan konflik dalam sebuah film harus mudah untuk dipahami oleh penonton dan digunakan untuk menarik penonton dengan membangkitkan emosional. Konflik mudah dipahami; Konflik yang ditampilkan dalam cerita akan mudah untuk dipahami apabila dibuat relatif datar, singkat dan tidak berulang-ulang sehingga tidak menimbulkan kebosanan. Konflik membangkitkan emosional; Supaya dapat membangkitkan sisi emosional penonton pada saat klimaks konfik dibuat berlebih tetapi tidak terlalu berlebih sehingga terlihat lebih nyata.

Bahasa film. Bahasa dalam film merupakan bahasa audio visual yaitu kombinasi antara bahasa suara dan bahasa gambar. Bahasa gambar; Bahasa gambar dapat berupa simbol dan tanda yang dapat menyampaikan pesan melalui penggambaran suatu keadaan atau cerita. Bahasa gambar dapat ditampilkan dengan gerak kamera 
untuk menggambarkan pesan serta maksud yang akan dikomunikasikan kepada penonton. Bahasa suara; Bahasa suara yang dimaksud adalah dialog. Dialog dibuat singkat tidak terlalu panjang dengan penggunaan bahasa yang memudahkan penonton untuk memahami maksudnya, memakai bahasa yang benar dan sesuai dengan aturan, singkat, padat dengan pesan moral menampilkan kata dan saran positif serta tidak menggunakan kata kasar yang dapat ditiru oleh penonton. Penggunaan kata asing dalam suatu film harus disertai subtitle sehingga penonton mengetahui maksud dari apa yang ingin disampaikan dalam sebuah adegan film.

Durasi penayangan film. Penayangan film yang efektif sebagai media promosi kesehatan terutama di sekolah harus disesuaikan dengan waktu pembelajaran siswa dan film yang tidak membosankan memiliki durasi pendek dalam penayangannya. Sesuai waktu pembelajaran; Film yang digunakan sebagai media promosi kesehatan di sekolah disesuaikan dengan alokasi waktu pembelajaran disekolah yaitu maksimal 2 X 45 menit per pertemuan dan dalam penayangannya dapat dilakukan berulang sehingga akan memberikan dampak kuat pada pribadinya. Durasi pendek; Film pendek dapat dijadikan film pendidikan karena durasi penayangan yang pendek dibawah 30 menit sehingga memiliki pemahaman bahasa gambar yang lebih jernih dengan menggunakan tanda atau simbol yang secara tidak langsung dapat menggambarkan suatu keadaan atau cerita. Unsur-unsur seperti tema cerita, ide cerita, alur cerita, isi pesan, latar, konflik, penokohan serta dialog dapat disampaikan secara utuh dalam waktu yang singkat dan pemanfaatan media komunikasinya dapat berlangsung efektif.

Tata artistik; Penataan artistik merupakan keseluruhan lingkungan fisik dari film yang terdiri dari setting, properti, kostum, tata rias, tata cahaya ditambah special effect dan efek audio. Setting; Setting yang sempurna adalah yang nyata karena mampu meyakinkan penonton bahwa film tersebut tampak sungguh-sungguh terjadi pada waktu sesuai dengan konteks cerita. Setting merupakan hal utama yang mendukung cerita film, menciptakan suasana dalam cerita, menonjolkan karakter tokoh yang ingin ditampilkan, dan menciptakan emosional. Property; Pemilihan properti yang tepat yaitu menggunakan property yang nyata akan sangat penting karena mampu menciptakan dan menonjolkan karakter tokoh dan memberikan kejelasan dalam suatu adegan. Kostum; Kostum yaitu segala hal yang dikenakan pemain bersama seluruh aksesorisnya dimana bukan sekedar penutup tubuh saja tetapi harus memiliki fungsi sesuai dengan ceritanya dan kostum dapat memberikan gambaran tentang karakter atau kepribadian dari pemain. Pemilihan kostum khususnya untuk film yang akan digunakan sebagai media pendidikan harus memperhatikan unsur sopan santun dan norma yang berlaku. Tata rias; Tata rias merupakan unsur artistik untuk menampilkan karakter tokoh sesuai dengan perkembangan konflik dalam cerita. Tata rias menjadikan tampilan pemain lebih menarik dalam kamera. Penggunaan tata rias pemain pada film pendidikan tidak terlalu berlebih tetapi dibuat alami sesuai dengan kebutuhan adegan dan memperhatikan sopan santun serta norma. Tata cahaya; Tata cahaya meliputi kualitas, arah, sumber serta warna cahaya dimana keempat unsur tersebut akan membentuk suasana serta emosional dalam sebuah film. Penggunaan cahaya dalam pengambilan gambar film disesuaikan dengan maksud dari suatu adegan film dan digunakan sesuai dengan keadaan tempat pengambilan gambar. Efek audio visual; Penambahan efek khusus dalam film dapat menjadi media komunikasi lebih menarik dan memudahkan dalam menyampaikan pesan. Efek khusus dibuat senyata mungkin dan dapat meyakinkan penonton bahwa film tersebut tampak sungguh-sungguh terjadi pada lokasi dan waktu sesuai konteks cerita filmnya. Cara menampilkan efek nyata dalam film yaitu dengan menggambarkan kehidupan yang benar terjadi di masyarakat, menampilkan gambaran bukti nyata atau dengan menyampaikan cerita dari pengalaman seseorang. Apabila semakin terlihat nyata suatu film maka penonton akan merasakan pengalaman langsung sehingga akan semakin banyak pula pengalaman yang didapatkannya.

Efek audio dapat dilakukan dengan penambahan lagu atau instrument musik yang sesuai dengan adegan yang ditampilkan sehingga dapat membentuk dan memperkuat emosional penonton. Musik latar yang mengiringi adegan atau selama cerita berlangsung juga akan membentuk dan memperkuat tema utama dari sebuah film. Menentukan musik yang sesuai perlu memperhatikan pemilihan jenis musik, lagu dan artis yang dapat mewakili isi dari adegan yang ditampilkan.

Penokohan. Penggambaran tokoh dalam suatu film akan mempengaruhi keberhasilan suatu film yang ditayangkan dapat dilakukan mulai dari pemilihan pemain dan pemilihan tokoh cerita. Pemilihan pemain; Hal pertama yang perlu diperhatikan dalam penokohan yaitu kemampuan seni peran, karena kemampuan pemeran akan menentukan kualitas film yang dihasilkan sehingga bakat yang dipilih adalah pemain yang sudah dapat berperan sesuai dengan karakternya. Pemilihan tokoh cerita; Penentuan 
karakter tokoh yang dipilih harus akrab dan sesuai dengan karakter penonton. Apabila tidak memungkinkan dapat menampilkan tokoh yang mempunyai pengaruh sosial seperti keluarga yaitu orang tua serta kelompok sebayanya dengan tujuan mengajak penonton untuk mencontoh halhal yang positif. Tokoh utama harus digambarkan memiliki karakter yang baik sehingga akan memengaruhi niat remaja untuk berbuat hal yang sama dengan tokoh yang dilihatnya. Untuk menarik dan menjadi pembanding maka dalam sebuah film dapat ditampilkan beberapa karakter. Karakter positif dapat menjadi model dengan perilaku yang baik atau memiliki perilaku sehat sedangkan karakter negatif dapat menjadi model dengan perilaku yang tidak baik atau memiliki perilaku tidak sehat yang berakhir dengan penderitaan. Penokohan yang diciptakan dalam sebuah film harus memiliki tujuan yang jelas untuk disampaikan kepada penonton. Hasil diperoleh bahwa untuk merancang dan membuat film yang efektif digunakan sebagai media promosi kesehatan khususnya mengatasi masalah perilaku merokok pada remaja perlu memperhatikan 9 komponen pendukung yaitu tujuan pembuatan film, tema film, konten atau isi pesan dari film, alur cerita, konflik dalam cerita film, bahasa film, durasi penayangan, tata artistik serta penokohan dalam cerita film. Akan tetapi yang perlu lebih diperhatikan untuk menghasilkan film yang akan digunakan sebagai media promosi kesehatan perlu lebih memperhatikan pada komponen tujuan yaitu pemanfaatannya sebagai sarana pembelajaran, tata artistik sehingga akan menarik penonton untuk melihat film yang ditayangkan dan penokohan yang sesuai dengan target sasaran, sehingga remaja sebagai target penonton dapat tertarik untuk melihat film tersebut dan dapat memperoleh pengetahuan yang lengkap, jelas dan benar tentang dampak buruk rokok bagi kesehatan, meningkatkan sikap berupa pengendalian diri untuk tidak merokok dan menumbuhkan kepercayaan diri menolak untuk merokok serta memotivasi untuk tidak merokok meskipun ada pengaruh dari lingkungan sekitarnya dan industri rokok melalui media terutama iklan rokok.

\section{Pembahasan}

Penelitian ini telah memberikan gambaran tentang film yang efektif digunakan sebagai media promosi kesehatan khususnya mengatasi masalah perilaku merokok pada remaja, namun penelitian masih memiliki keterbatasan diantaranya artikel jurnal dan buku teks serta katalog pustaka yang berasal dari perguruan tinggi hanya diambil dari
2 perguruan tinggi di bidang perfilman .

Saran, Selanjutnya hasil penelitian ini diharapkan dapat menjadi dasar dalam pembuatan film yang dapat digunakan sebagai media promosi kesehatan tentang rokok dan bahayanya bagi remaja.

\section{Daftar Pustaka}

1. Gusti, Sarake M, Ikhsan M. Faktor yang Mempengaruhi Jumlah Rokok yang Dihisap Perhari pada Remaja Pria di SMA Negeri 1 Bungku Selatan Kecamatan Bungku Selatan Kabupaten Morowali di Sulawesi Tengah Tahun 2013. Makasar : Bagian Biostatistik/ KKB, Fakultas Kesehatan Masyarakat, UNHAS ; 2015.

2. Kholid A. Promosi Kesehatan dengan Pendekatan Teori Perilaku, Media dan Aplikasinya (Untuk Mahasiswa dan Praktisi Kesehatan). Depok: PT Rajagrafindo Persada; 2014.

3. Notoatmodjo S. Pendidikan dan Perilaku Kesehatan. Jakarta: Rineka Cipta; 2007.

4. Kumboyono. Perbedaan Efek Penyuluhan Kesehatan Menggunakan Media Cetak dengan Media Audio Visual Terhadap Peningkatan Pengetahuan Pasien Tuberkulosis. Program Studi Ilmu Keperawatan FK Universitas Brawijaya. Jurnal Ilmiah Kesehatan Keperawatan. Volume 7, No. 1 Februari 2011. Malang : Program Studi Ilmu Keperawatan FK Universitas Brawijaya ; 2011.

5. Film Sebagai Media Pembelajaran. [diunduh 15 Maret 2016]. Tersedia dari http://neozonk. wordpress.com/2012/09/17/film-sebagaimedia-pembelajaran/.

6. Prakosa G. Film Pinggiran (Antologi Film Pendek, Film Eksperimental dan Film Dokumenter). Jakarta: FFTV-IKJ dan YLP; 2008.

7. Prakosa G. Film Pendek Independen Dalam Penilaian (Sebuah Catatan dari Berbagai Festival "Film Pendek dan Film Alternatif" di Indonesia) Cetakan Perdana. Jakarta: Komite Film Dewan Kesenian Jakarta dan Yayasan Seni Visual Indonesia; 2005.

8. Hunt K, Henderson M, Wight D, Sargent JD. Exposure To Smoking In Films And Own Smoking Among Scottish Adolescents: A Cross Sectional Study. Thorax, 2011 October ; 66(10): 866-874. doi: 10.1136/ thoraxjnl-2011-200095; 2011.

9. Thrasher JF, Sargent JD, Huang L, Santillan EA, Alonso AD, Hernandez RP. Does Film Smoking Promote Youth Smoking In Middle Income Countries ? A Longitudinal Study 
Among Mexican Adolescents. Cancer Epidemiol Biomarkers Prev. 2009 December ; 18(12): doi:10.1158/1055-9965.EPI-09$0883 ; 2009$.

10. Thrasher JF, Jackson C, Santillan EA, Sargent JD. Exposure To Smoking Imagery In Popular Films And Adolescent Smoking In Mexico. Am J Prev Med. 2008 August; 35(2):95-102. doi: 10.1016/j.amepre.2008.03.036; 2008.

11. Primack BA, Longacre MR, Beach ML, Mejia AMA, Titus LJ, Dalton MA. Association Of Established Smoking Among Adolescents With Timing Of Exposure To Smoking Depicted In Movies. DOI: 10. 1093/jnci/djs 138; 2012

12. Dixon HG, David JH, Borland R, Paxton SJ. Public Reaction To The Portrayal Of The Tobacco Industry In The Film The Insider. Tobacco Control 2011; 10:285-291; 2011.

13. Anderson SJ, Millett C, Polansky JR, Glantz SA. Exposure To Smoking In Movie Among British Adolescents 2001-2006. Tobacco Control 2010; 19:197-200. doi: 10.1136/ tc. 2009.034991; 2010.

14. Song AV, Ling PM, Neilands TB, Glantz SA. Smoking In Movies And Increased Smoking Among Young Adults. Am J Prev Med. 2007 November ; 33(5): 396-403. doi: 10.1016/j. amepre.2007.07.026; 2007.

15. Charlesworth A, Glantz SA. Smoking In The Movies Increases Adolescent Smoking: A Review. PEDIATRICS Vol.116 No, 6 December 2005; 2005.

16. Sargent JD, Beach ML, Dalton MA, Mott LA, Tickle JJ, Ahrens MB, Heatherton TF. Effect Of Seeing Tobacco Use In Films On Trying Smoking Among Adolescents: Cross Sectional Study. BMJ Volume 32315 December 2011; 2011.

17. Edwards C, Oakes W, Bull D. Out Of The Smokescreen II: Will An Advertisement Targeting The Tobacco Industry Affect Young People's Percption Of Smoking In Movie And Their Intention To Smoke ?. Tobacco Control 2007; 16:177-181. doi: 10.1136/ tc. $2006.017194 ; 2007$. 